\title{
Antipyrine Space Studies and Cell Water Estimates in Infants of Low Birth Weight
}

\author{
George Cassady ${ }^{[49}$ and Rachel R. Milstead \\ Pcrinatal Rescarch Laboratory, Department of Pediatrics, University of Alabama Medical Center, Birmingham, Alabama, USA
}

\section{Extract}

Antipyrine space (APS) studies in 44 normally grown (NG) neonates revealed estimates of total body water (TBW) comparable to those found by earlier investigators utilizing desiccation analyses. Body water per kilogram of body weight was higher in the 32 premature infants than in the 12 mature neonates, even after correction for presumed changes in body fat during growth (mean APS/lean mass was $846 \mathrm{ml} / \mathrm{kg}$ in premature and $782 \mathrm{ml} / \mathrm{kg}$ in mature infants, $P<0.01$ ), suggesting less hydration of lean mass with maturity. Cell water (ICW) estimates, obtained by concurrent bromide and antipyrine dilution studies revealed no differences between mature and premature neonates after fat corrections (mean ICW $/$ lean mass was $391 \mathrm{ml} / \mathrm{kg}$ in premature and $368 \mathrm{ml} / \mathrm{kg}$ in mature neonates, $P>0.10$ ). Prompt decrease in cell water was evident in the mature NG infants (correlation coefficient for ICW/APS versus study age: $r=-0.76$; ICW versus study age: $r=-0.58$ ), whereas such changes were absent in the premature infants (ICW/APS versus study age: $r=-0.08$; ICW versus study age: $r=-0.16$ ).

Total water and cell water estimates in 23 intrauterine growth-retarded (IGR) neonates also studied were comparable to those of weight peers (mean APS, $790 \mathrm{ml} / \mathrm{kg}$ and ICW, $379 \mathrm{ml} / \mathrm{kg}$ in IGR; mean APS, $809 \mathrm{ml} / \mathrm{kg}$ and ICW, $375 \mathrm{ml} / \mathrm{kg}$ in NG prematures) but considerably in excess of values seen in gestational peers (mean APS, $688 \mathrm{ml} / \mathrm{kg}$ and ICW, $324 \mathrm{ml} / \mathrm{kg}$ in NG mature infants). The high total body water and cell water values were particularly prominent in the earlier-studied IGR infants (mean APS, $841 \mathrm{ml} / \mathrm{kg}$ and ICW, $494 \mathrm{ml} / \mathrm{kg}$ ); a notable finding was the rapid downward adjustment of cell water to values similar to those in NG mature infants (ICW, $335 \mathrm{ml} / \mathrm{kg}$ in later-studied IGR infants and $314 \mathrm{ml} / \mathrm{kg}$ in later-studied NG mature neonates). This expansion of cell water in earlier-studied IGR infants persisted despite correction for a presumed total depletion of body fat (ICW/lean mass, $494 \mathrm{ml} / \mathrm{kg}$ in IGR infants, and $389 \mathrm{ml} / \mathrm{kg}$ in NG mature babies; ICW/APS was 0.56 in IGR neonates and 0.50 in NG mature infants, $P<0.001$ for both). These findings indicate a real increase in cell water at birth in the IGR infant.

\section{Speculation}

Changes in body composition in infants with intrauterine growth retardation (IGR) include sizable expansions, on a per kilogram basis, of all body water compartments. Although these findings resemble those observed in chronic protein-calorie malnutrition, rapid adjustments toward normal in the early hours after birth suggest a more transient, acute expansion, primarily of cell water, in the IGR neonate. These changes may reflect impaired cellular metabolism and increased cell acidity consequent to an increased asphyxial stress of labor and delivery in these infants. 


\section{Introduction}

Low birtl weight may result from either premature birth or impaired fetal growth. Clinical consequences in these small babies, including perinatal morbidity and mortality as well as ultimate physical and intellectual achievement, appear intimately related to the causative factors $[14,28]$. Both groups of infants demonstrate changes in body composition reflecting either interrupted or disturbed developmental sequences when compared with mature, normally grown (NG) neonates. Previous studies from this laboratory have recorded the similarity of alterations in 10-min albumin space ("plasma volume") [8] and 3-hr bromide space ("extracellular volume") [9] in fetal growth-retarded neonates to those changes observed in postnatal protein-calorie malnutrition $[10,19,20]$. The present report presents observations concerning concurrent measurements of antipyrine and bromide spaces in 67 neonates delivered vaginally and studied within $24 \mathrm{hr}$ of birth.

\section{Materials and Methods}

Umbilical venous catheterization and injection of a sterile solution containing $2 \% \mathrm{NaBr}$ and $0.5 \%$ antipyrine (1-phenyl-2,3-dimethylpyrazolone-5-one) were done in all study infants [9, 46]. Quantity of bromide injected averaged $65 \mathrm{mg} / \mathrm{kg}$ (range, 37-93 $\mathrm{mg} / \mathrm{kg}$ ); concentrations of plasma bromicle ranged from 9 to $2 \mathrm{I}$ $\mathrm{mg} / 100 \mathrm{ml}$ (mean, $14.3 \mathrm{mg} / 100 \mathrm{ml}$ ). Quantity of antipyrine injected averaged $10 \mathrm{mg} / \mathrm{kg}$ (range, $6-13 \mathrm{mg}$ / $\mathrm{kg}$ ); concentrations of plasma antipyrine ranged from 0.75 to $1.72 \mathrm{mg} / 100 \mathrm{ml}$ (mean, $1.31 \mathrm{mg} / 100 \mathrm{ml}$ ).

The corrected bromide space (CBS) was estimated in precisely the same manner as previously clescribed [9]. Levels of plasma antipyrine were estimated in chuplicate on 1-, 3-, and 5-hr postinjection samples using the micromethod of Mendelsohn and Levin [3, 32]; average coefficient of variation was $2.2 \%$. Antipyrine space (APS) was estimated from zero-time dilution as extrapolated from these concentrations using the leastsquares method for estimating best fit of these points to the $y=a+b x$ equation [13]. Slopes of these regression lines ranged from +0.04 to -0.10 (average, -0.021 ). The formula used was:

antipyrine space, $\mathrm{ml}$

$$
=\frac{\text { antipyrine injected, } \mathrm{mg}}{\text { zero-time plasma antipyrine conc, } \mathrm{mg} / \mathrm{ml}} \times 0.934
$$

Cell water was estimated as the difference between APS and CIBS (ICW $=$ APS - CBS). Because of our inabil- ity to express in vivo data on a "fat-free lean mass" basis and in order to minimize the effects of altered body fat on these results, ICW/APS ratios were calculated as additional estimates of cell water.

Environmental conditions during these studies and methods used in classification of infants as normally grown, moderately growth-retarded or severely growthretarded have previously been described in detail [810]. As in previous studies, the cord was generally clamped after the first breath; therefore, study infants received a placental transfusion.

Intravenous fluid therapy was required by clinical circumstances in 21 study infants (all of them $N G$ neonates). Parenteral fluid was required more commonly in premature (20 of 32 ) than in mature infants (l of 12). An average of $55 \mathrm{ml}$ isosmolar fluid (range, $8-195 \mathrm{ml}$ ) was provided for these infants. Eleven study infants (three NG, eight IGR) were fed a total of $0.5-2$ o $5 \%$ dextrose prior to and/or during the study.

\section{Results}

\section{Clinical Characteristics}

Race, sex, birth weights, gestational intervals, and physical characteristics of the 67 study infants are summarized in Table I. The birth weights of 44 normally grown (NG) neonates were appropriate for their gestational age [10]. Thirty-two of these $N G$ infants were premature: average gestational age was 31 weeks and mean birth weight was $1675 \mathrm{~g}$. Intrauterine growth retardation (IGR) was present in 23 infants, all of whom were mature with birth weights of less than $2500 \mathrm{~g}$.

\section{Normally Grown Neonates}

Table II presents the relation of antipyrine space (APS, in liters) and cell water estimates (ICW, in liters and ICW/APS) to variables of fetal maturity in the NG infants. A significant $(P<0.001)$ direct relation for both APS and ICW with each of these variables was apparent. Values for APS appear most simply related to birth weight, whereas ICW estimates appear better related to length. Unexpectedly, the ICW/APS ratio was not significantly related $(P>0.10)$ to any of the variables analyzed. The data for APS are scatter plotted against birth weight along with body water data from previous in vivo studies $[11,17,18]$ and from 25 carcass studies $[1,3-7,15,21,24,25,33,34,39,42,45]$ in comparable subjects (Fig. 1). Allometric relations [23] between these variables are expressed by the following equations: 
Table I. Clinical characteristics of study infants

\begin{tabular}{|c|c|c|c|c|c|c|c|}
\hline Infant study group) & $\begin{array}{l}\text { No. of } \\
\text { infants }\end{array}$ & $\operatorname{Sex}, \mathrm{M} / \mathrm{F}$ & $\begin{array}{l}\text { Race, } \\
N / W\end{array}$ & $\begin{array}{c}\text { Mean } \\
\text { gestational } \\
\text { interval, wh }\end{array}$ & $\begin{array}{l}\text { Mean } \\
\text { birth wcight, g }\end{array}$ & $\begin{array}{c}\text { Mean } \\
\text { crown-heel } \\
\text { length, cm }\end{array}$ & $\begin{array}{c}\text { Mean } \\
\text { occipito-frontal } \\
\text { head circumference, } \mathrm{cm}\end{array}$ \\
\hline \multicolumn{8}{|l|}{ Normally grown } \\
\hline $22-32$ weeks & 17 & $10 / 7$ & $15 / 2$ & 28 & $\begin{array}{c}1320 \\
(740-2100)^{1}\end{array}$ & $\begin{array}{c}40 \\
(31-45)\end{array}$ & $\begin{array}{c}28 \\
(23-32)\end{array}$ \\
\hline $33-36$ wecks & 15 & $7 / 8$ & $14 / 1$ & 34 & $\begin{array}{c}2085 \\
(1760-2480)\end{array}$ & $\begin{array}{c}45 \\
(40-48)\end{array}$ & $\begin{array}{c}31 \\
(28-35)\end{array}$ \\
\hline $37-43$ wecks & 12 & $5 / 7$ & $10 / 2$ & 41 & $\begin{array}{c}3190 \\
(2720-3740)\end{array}$ & $\begin{array}{c}51 \\
(47-57)\end{array}$ & $\begin{array}{c}34 \\
(32-35)\end{array}$ \\
\hline \multicolumn{8}{|l|}{ Growth-retarded } \\
\hline $37-47$ wecks & 23 & $6 / 17$ & $16 / 7$ & 39 & $\begin{array}{c}2145 \\
(1700-2460)\end{array}$ & $\begin{array}{c}45 \\
(42-48)\end{array}$ & $\begin{array}{c}32 \\
(28-34)\end{array}$ \\
\hline
\end{tabular}

1 Numbers in parentheses indicate range of values.

Table II. Relation between study variables in normally grown neonates ${ }^{1}$

\begin{tabular}{|c|c|c|c|c|c|c|c|c|c|}
\hline $\begin{array}{l}\text { Dependent } \\
\text { variable }\end{array}$ & $=$ & Intercept & + & Slope & $x$ & $\begin{array}{l}\text { Independent } \\
\text { variable }\end{array}$ & $\begin{array}{l}\text { Correlation } \\
\text { coeflicient }\end{array}$ & $s_{\mathrm{y} \cdot \mathrm{x}^{2}}$ & $\begin{array}{l}\text { No. of } \\
\text { infants }\end{array}$ \\
\hline \multirow[t]{5}{*}{ APS, liters } & & -1.389 & & +0.088 & & Gestational age, wk & +0.916 & \pm 0.166 & 44 \\
\hline & & +0.288 & & +0.606 & & Birth weight, kg & +0.953 & \pm 0.161 & 44 \\
\hline & & -2.259 & & +0.086 & & Length, cm & +0.922 & \pm 0.217 & 40 \\
\hline & & -2.533 & & +0.134 & & Head circumference, $\mathrm{cm}$ & +0.860 & \pm 0.236 & 39 \\
\hline & & -0.223 & & +11.124 & & Surface area, $\mathrm{m}^{2}$ & +0.957 & \pm 0.141 & 40 \\
\hline \multirow[t]{5}{*}{ ICW, litcrs } & & -0.682 & & +0.042 & & Gestational agc, wk & +0.791 & \pm 0.137 & 34. \\
\hline & & +0.166 & & +0.272 & & Birth weight, kg & +0.794 & \pm 0.151 & 34 \\
\hline & & -1.595 & & +0.052 & & Leng th, $\mathrm{cm}$ & +0.852 & \pm 0.129 & 32 \\
\hline & & -1.208 & & +0.064 & & Head circumference, $\mathrm{cm}$ & +0.722 & \pm 0.154 & 32 \\
\hline & & -0.118 & & +5.291 & & Surface arca, $\mathrm{m}^{2}$ & +0.804 & \pm 0.147 & 32 \\
\hline \multirow[t]{5}{*}{$\mathrm{ICW} / \Lambda \mathrm{PS}$} & & +0.384 & & +0.002 & & Gestational age, wk & +0.179 & \pm 0.084 & 34 \\
\hline & & +0.447 & & +0.00001 & & Birth weight, kg & +0.080 & \pm 0.101 & 34 \\
\hline & & +0.293 & & +0.00374 & & Leng th, cm & +0.253 & \pm 0.055 & 32 \\
\hline & & +0.439 & & +0.001 & & Head circumference, $\mathrm{cm}$ & +0.035 & \pm 0.009 & 32 \\
\hline & & +0.440 & & +0.135 & & Surface area, $\mathrm{m}^{2}$ & +0.084 & \pm 0.059 & 32 \\
\hline
\end{tabular}

${ }_{1}$ Regression analyses of relations between antipyrine space ( $A P S$ ), cstimated intracellular water (ICW) and ICW/APS ratio in normally grown study infants.

$2 s_{y \cdot \mathrm{x}}:$ standard crror of the estimate [13, p. 119].

$\log$ APS, liters $=0.8524 \times \log$ birth weight, $\mathrm{kg}-$ 0.0777 (correlation coefficient $=+0.972 ; \log$ $\left.s_{\mathrm{y} \cdot \mathrm{x}}= \pm 0.0385\right)$

$\log \mathrm{ICW}$, liters $=3.3162 \times \log$ length, $\mathrm{cm}-5.6301$ (correlation coefficient $=+0.858 ; \log s_{y \cdot x}= \pm$ $0.0778)$

As both linear and $\log$ correlation coefficients are less than 1, curvilinearity in these relations is suggested. In order to compare these data with figures from other investigators, they are presented in Table III as ratio standards (percentage of body weight in milliliters per kilogram). These data reveal a larger mean APS (more than $100 \mathrm{ml} / \mathrm{kg})$ in premature neonates $(809 \pm \mathrm{I}(0.6 \mathrm{sr})$ when they are contrasted with mature infants (688 \pm $16.2 \mathrm{se})$. The apparent increase in mean cell water in the premature group (ICW almost $50 \mathrm{ml} / \mathrm{kg}$ higher) was not accompanied by any significant or suggestive change in mean ICW/APS ratio.

Prompt postnatal adjustments in body water with fluid redistribution between these dilution spaces have been suggested by Maclaurin [29]. Such changes may obscure intergroup differences. Data from the present study, presented in terms of study age in Figure 2 and Table IV, reveal remarkably little change in mean APS between early ( $<6 \mathrm{hr}$ of birth) and later studied (6 hr or more of birth) NG infants, whether mature or premature. Body water redistribution with transfer from cell to extracellular compartments is suggested 


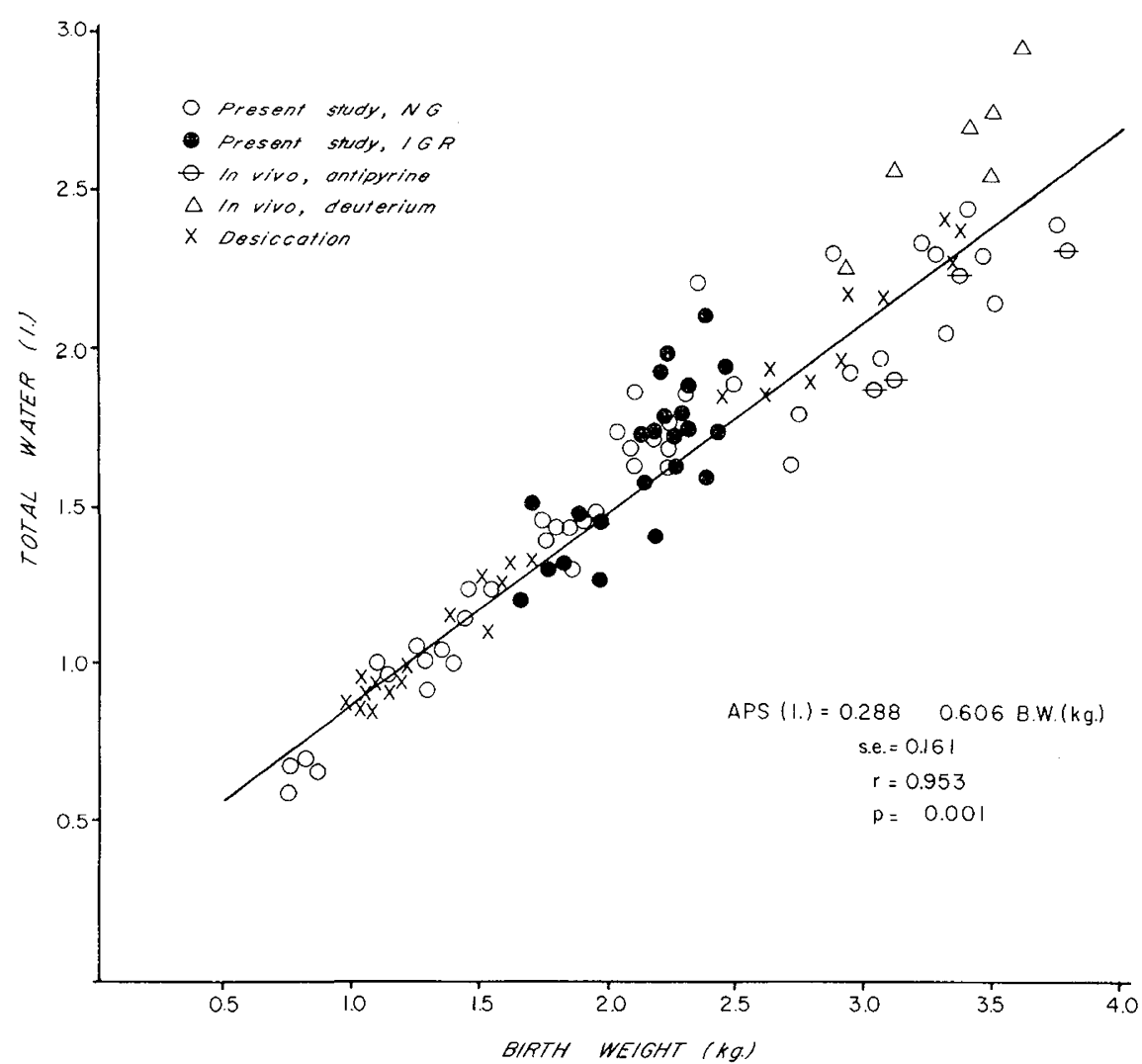

Fig. 1. Relation between estimated total body water (in liters) and birth weight (in kilograms). Individual data from 10 presumably normally grown infants studied within $24 \mathrm{hr}$ of birth $[17,11]$ and 25 desiccation analyses (see text) are scatterplotted with data from 44 normally grown and 23 growth-retarded neonates in the present report. The regression equation for data from the present study is superimposed as a solid line.

in the mature infants both from grouped averages and regression analyses: mean ICW diminished from 343 to $314 \mathrm{ml} / \mathrm{kg}$ and mean ICW/APS declined from 0.50 to 0.45 whereas the correlation coefficient for ICW versus study age $=-0.58$ and for ICW/APS versus study age $=-0.76$. There was no suggestion of diminishing cell water in the premature infants (Table IV).

Study age does not influence the higher APS per kilogram in the premature infants. In both early- and late-studied groups, mean APS was larger in premature than in mature NG infants; 796 versus $682 \mathrm{ml} / \mathrm{kg}, P$ $<0.02$, and 824 versus $691 \mathrm{ml} / \mathrm{kg}, P<0.001$, respectively.

\section{Intrauterine Growth-retarded Neonales}

Table $\mathrm{V}$ provides details concerning the relation of mean APS and ICW estimates with variables of fetal maturity in the 23 IGR neonates. Again, APS appears best expressed in terms of birth weight (Fig. 1) and this relation is similar to that in NG infants $(F=1.239)$. Mean ICW in the IGR group correlates only with birth weight and surface area, and ICW/APS ratio does not correlate with any parameter of fetal maturity in this group.

These same data are expressed as percentage of body weight (milliliters per kilogram) in Tables III and IV and in Figure 3. The significantly higher mean APS values in the IGR group (more than $100 \mathrm{ml} / \mathrm{kg}$ ) are shown in Figure 3 in which individual APS values in $I G R$ infants are superimposed on mean \pm 1 so range for the NG infants. Mean ICW and ICW/APS ratios are similar in NG and IGR groups (also shown in Fig. 3).

Study age affects these findings. Comparison of earlystudied IGR neonates with NG mature infants clearly revealed real differences between these groups (Fig. 2 and Table IV). Redistribution of body water in the IGR infant is rapid and apparent. Prompt decline in estimated ICW, evident in both groups, was particularly notable in the IGR group; the significant expansion of cell water in the IGR infants (mean ICW more than $150 \mathrm{ml} / \mathrm{kg}$ higher) was apparent only within the 
Table III. Group comparisons ${ }^{I}$

\begin{tabular}{|c|c|c|c|c|c|c|c|c|c|}
\hline \multirow{2}{*}{$\begin{array}{l}\text { Group comparisons of } \\
\text { study infants }\end{array}$} & \multicolumn{4}{|c|}{ APS } & \multicolumn{3}{|c|}{ ICW } & \multicolumn{2}{|c|}{ ICW/APS } \\
\hline & $N^{2}$ & & $\mathrm{ml} / \mathrm{kg}$ & $P$ & $N$ & $\mathrm{ml} / \mathrm{kg}$ & $P$ & Ratio & $P$ \\
\hline Normally grown mature & 12 & 688 & $\pm 16.2^{3}$ & & 11 & $324 \pm 17.1$ & & $0.47 \pm 0.016$ & \\
\hline $\begin{array}{l}\text { Versus normally grown prema- } \\
\text { ture }\end{array}$ & 32 & 809 & \pm 10.6 & $<0.001$ & 23 & $375 \pm 15.1$ & $<0.05$ & $0.46 \pm 0.013$ & $\mathrm{~ns}^{1}$ \\
\hline Versus IGR $^{5}$ mature & 23 & 790 & \pm 13.0 & $<0.001$ & 18 & $379 \pm 21.9$ & ns & $0.46 \pm 0.020$ & $\mathrm{~ns}$ \\
\hline
\end{tabular}

${ }^{1}$ Statistical analyses of certain apparent differences in grouped averages for antipyrine space (APS) and cell water estimates (ICW, ICW/APS).

${ }^{2} N$ : number of infants.

3 Mean $\pm 1 \mathrm{SE}$.

${ }^{4}$ ns: not significant $(P>0.05)$.

${ }^{5}$ IGR: intrauterine grow th-retarded.

Table $I V$. Relation of study age to neonatal body water compartments

\begin{tabular}{|c|c|c|c|c|c|c|c|c|c|c|c|c|c|c|c|}
\hline \multirow{3}{*}{$\begin{array}{l}\text { Infant study } \\
\text { group, } N^{1}\end{array}$} & \multicolumn{5}{|c|}{ APS, $\mathrm{ml} / \mathrm{kg}$} & \multicolumn{5}{|c|}{$\mathrm{ICW}, \mathrm{ml} / \mathrm{kg}$} & \multicolumn{5}{|c|}{ ICW/APS } \\
\hline & \multicolumn{3}{|c|}{$\begin{array}{l}\text { Grouped } \\
\text { averages }\end{array}$} & \multicolumn{2}{|c|}{$\begin{array}{l}\text { Regression } \\
\text { analysis }^{4}\end{array}$} & \multicolumn{3}{|c|}{$\begin{array}{l}\text { Grouped } \\
\text { averages }\end{array}$} & \multicolumn{2}{|c|}{$\begin{array}{l}\text { Regression } \\
\text { analysis }\end{array}$} & \multicolumn{3}{|c|}{$\begin{array}{l}\text { Grouped } \\
\text { averages }\end{array}$} & \multicolumn{2}{|c|}{$\begin{array}{c}\text { Regression } \\
\text { analysis }\end{array}$} \\
\hline & Early² & Late $^{3}$ & $P$ & $r^{5}$ & $P$ & Jarly & Late & $P$ & $r$ & $P$ & Early & Late & $P$ & $r$ & $P$ \\
\hline $\begin{array}{l}\text { Normally grown } \\
\text { mature (12) }\end{array}$ & $\begin{array}{l}682 \\
\pm 15.0^{6}\end{array}$ & $\begin{array}{l}691 \\
\pm 23.8\end{array}$ & $n s^{7}$ & -0.19 & ns & $\left|\begin{array}{l}343 \\
\pm 11.6\end{array}\right|$ & $\left|\begin{array}{l}314 \\
\pm 26.0\end{array}\right|$ & $\mathrm{ns}$ & $-0.58 \mid$ & ns & $\left|\begin{array}{l}0.50 \\
\pm 0.011\end{array}\right|$ & $\mid \begin{array}{l}0.45 \\
\pm 0.022\end{array}$ & ns & -0.76 & $<0.01$ \\
\hline $\begin{array}{c}\text { Normally grown } \\
\text { premature }(32)\end{array}$ & $\begin{array}{l}796 \\
\pm 20.2\end{array}$ & $\left|\begin{array}{l}824 \\
\pm 11.1\end{array}\right|$ & ns & +0.21 & ns & $\begin{array}{l}373 \\
\pm 27.4\end{array}$ & $\begin{array}{l}377 \\
\pm 17.4\end{array}$ & ns & -0.08 & ns & $\begin{array}{l}0.46 \\
\pm 0.022\end{array}$ & $\begin{array}{l}0.46 \\
\pm 0.016\end{array}$ & ns & -0.16 & $\mathrm{~ns}$ \\
\hline IGR: mature (23) & $\begin{array}{l}841 \\
\pm 27.1\end{array}$ & $\begin{array}{l}772 \\
\pm 12.5\end{array}$ & $<0.02$ & -0.38 & $\mathrm{~ns}$ & $\begin{array}{l}494 \\
\pm 12.5\end{array}$ & $\left\{\begin{array}{l}335 \\
\pm 18.2\end{array}\right.$ & $<0.001$ & -0.61 & $<0.01$ & $\left\{\begin{array}{l}0.56 \\
\pm 0.017\end{array}\right.$ & $\begin{array}{l}0.43 \\
\pm 0.018\end{array}$ & $<0.001$ & -0.55 & $<0.02$ \\
\hline
\end{tabular}

${ }^{1} N$ : number of infants studied, in parentheses.

${ }^{2}$ Early: study age $<6 \mathrm{hr}$ after birth.

${ }^{3}$ Late: study age $6 \mathrm{hr}$ or more after birth.

${ }^{4} Y: a+b x$ calculated from least squares cquation.

" $r$ : correlation coefficient.

${ }^{6}$ Mean $+1 \mathrm{se}$.

7 ns: not significant $(P>0.05)$.

${ }^{8}$ IGR: in trauterine grow th retarded.
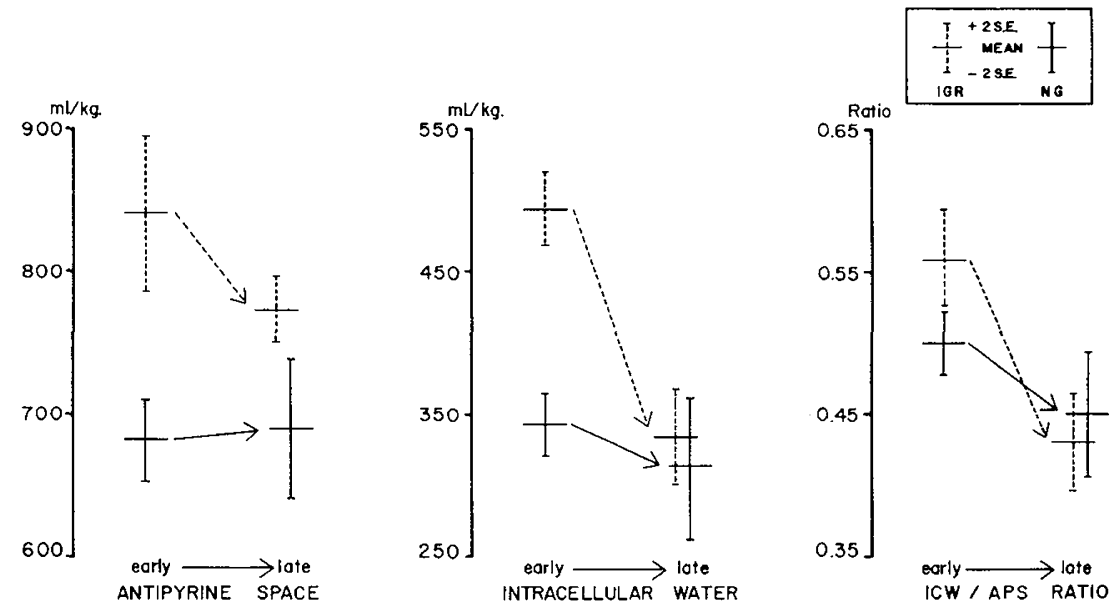

Fig. 2. Effect of study age on body water compartments in mature study infants. Mean and $2 \mathrm{sE}$ ranges are indicated by bar and brackets, respectively; solid figures indicate normally grown (NG) infants and broken figures indicate growth retarded (IGR) infants. Study $<6$ hr from birth was considered "carly" while studies 6-24 hr after birth were considered "late." 
Table $V$. Relation between study variables in growth-retarded neonates ${ }^{1}$

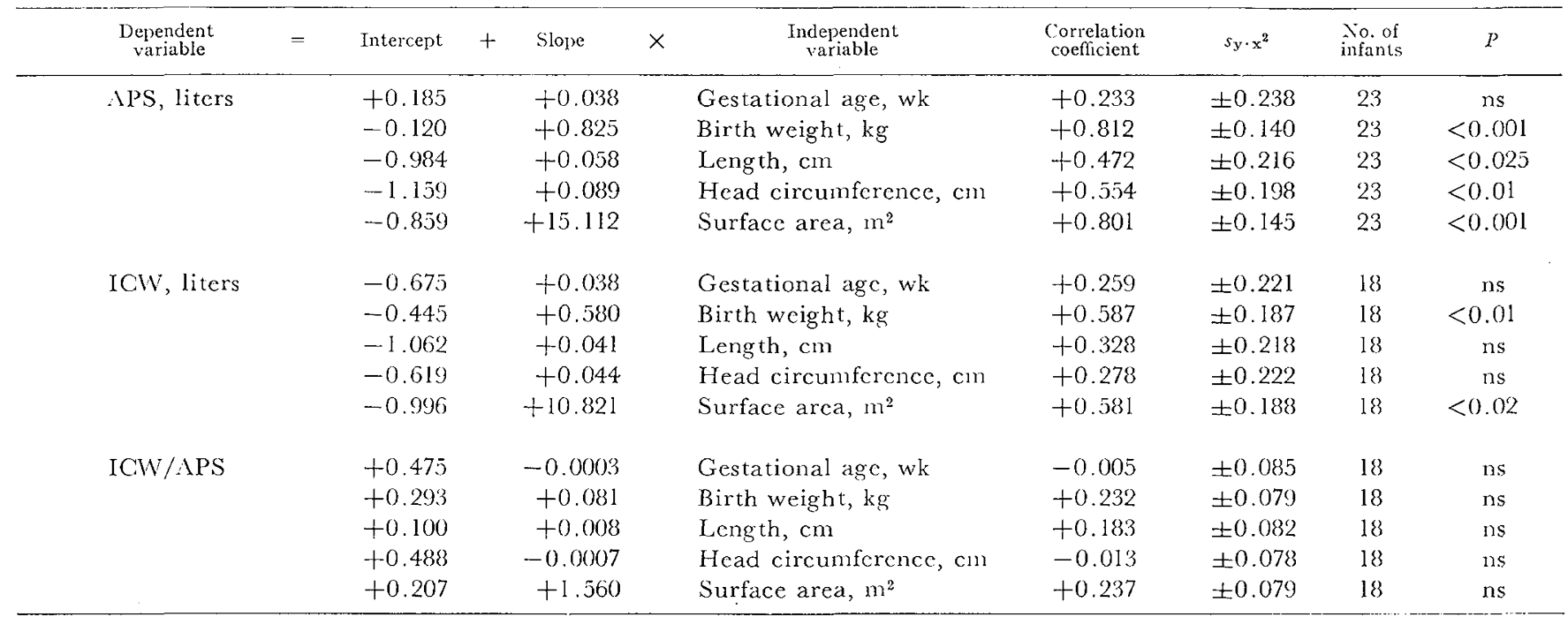

${ }^{1}$ Regression analyses of relations between antipyrine space (APS), estimated intracellular water (ICW and ICW/APS) and certain parameters of maturity in growth-retarded study infants.

$s_{y \cdot x}:$ standard error of the estimate.
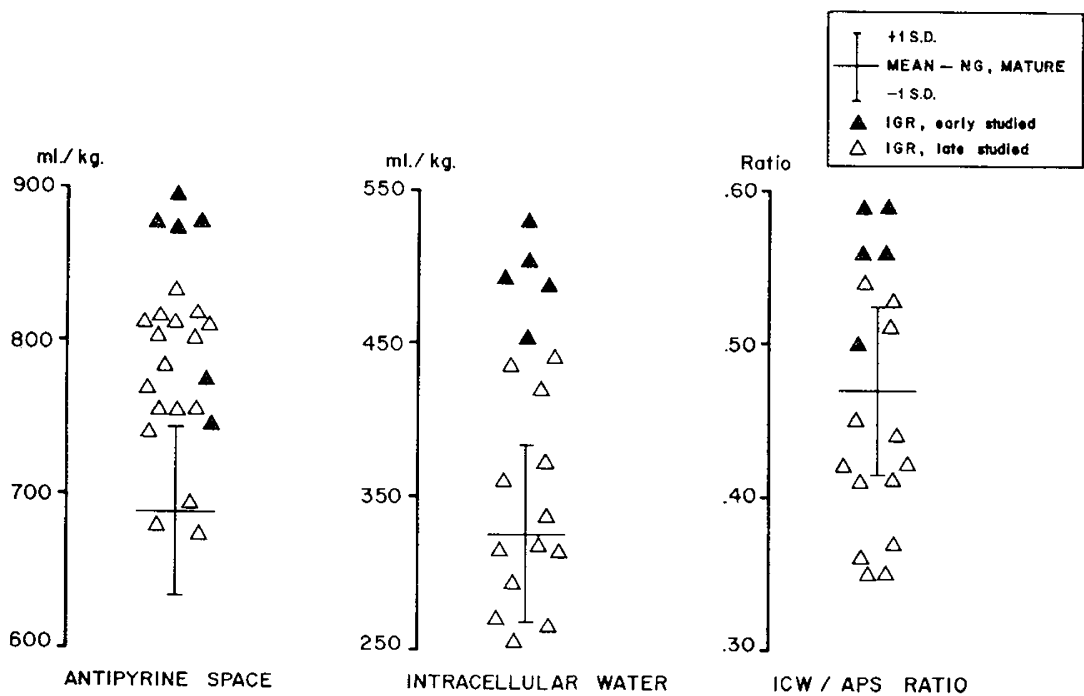

Fig. 3. Effect of study age and intrauterine growth retardation (IGR) on antipyrine space (APS), intracellular water ( $A$ PS minus corrected bromide space) and ICW/APS ratio. Individual data from IGR infants are supcrimposed on mean $t 1$ sD ranges for the normally grown infants (NG) from this study. $\Delta$ : early study age ( $<6 \mathrm{hr}$ from birth). $\triangle$ : late study age (6-24 $\mathrm{hr}$ from birth).

first 6 hr of extrauterine life, with mean ICW values in IGR and NG neonates virtually identical by $6 \mathrm{hr}$ of age. Also notable was the fact that the mature IGR infants adjusted cell water downward in the same manner as clicl mature NG neonates, whereas APS per kilogram, ICW per kilogram, and ICW/APS were remarkably unaffected by study age in the premature NG infants.

\section{Discussion}

Mean in vivo total body water (TBW) estimates in the human fetus and neonate by previous authors range from 633 to $882 \mathrm{ml} / \mathrm{kg}[11,12,16-18,22,29,41]$; consistently higher estimates have been obtained with deuterium than with antipyrine [17, 18, 27]. Cell water data are sparse, mean estimates ranging from 347 to 448 $\mathrm{ml} / \mathrm{kg}[12,16-18,29,41]$. Diminishing TBW per kilogram and ICW per kilogram has been suggested with advancing gestational maturity $[40,44]$, but this concept is difficult to prove because of vagaries in study age, clinical status, postnatal age, and technique in the data as presented. The standard of reference for any body water dilution technique is its relation to results obtained by carcass analysis (desiccation). These values 
range from 660 to $755 \mathrm{ml} / \mathrm{kg}$ (mean, $716 \mathrm{ml} / \mathrm{kg}$ ) [ [ , 5-7, $15,21,24,39,15]$ in mature inlants and from 739 to 855 $\mathrm{ml} / \mathrm{kg}$ (mean, $812 \mathrm{ml} / \mathrm{kg}$ ) in infants with birth weights of $1010-176 \mathrm{~g} g[4,15,2 \mathrm{I}, 24,25,33,34]$. Mean antipyrine dilution space was $688 \pm 16.2 \mathrm{ml} / \mathrm{kg}$ sE in 12 mature infants and $809 \pm 10.6 \mathrm{ml} / \mathrm{kg}$ se in 32 premature NG neonates evaluated within 24 hr of birth in the present study; comparability of these figures to the desiccation data is apparent.

Best expression of body water as a linear or log-log function of maturity is achieved by using birth weight; scatter plot of these data superimposed on the regression equation $(r=+0.972)$ has a distinct curvilinear quality suggesting, as in previous bromide space data [9], that a diminishing fraction of body mass is occupied by water as gestational maturity advances. This observation is strengthened by the differences in APS per kilogram in premature and in mature NG infants as well as by the "reductio ad absurdum" of both linear. and $\log$-log equations to a point where body water exceeds birth weight shown in the linear relation of TBW with birth weight in Figure 1 with weights < $700 \mathrm{~g})$.

One possible explanation for this nonlinearity relates to the fact that fat accumulates as fetal maturity advances. Mean body fat of $4.1 \%$ (range, 1.8-8.7\%) found by desiccation of infants with birth weights of 1010-1761 g $[4,15,24,25,33,34]$ is much less than mean fat of $11.4 \%$ (range, $6.7-16.1 \%$ ) in carcass analyses from mature neonates $[1,5-7,15,21,24,39]$ or the $12.3 \%$ in six of seven mature neonates with birth weights $<1000 \mathrm{~g}(2652-2994 \mathrm{~g})$ recently studicd by Widdowson and Spray [45]. Adclition of fat to body mass diminishes the proportion of body weight contributed by other constituents, indirectly reducing body water (APS per kilogram) in patients with excess bocly fat. Recalculation of the present data, assuming $4 \%$ body fat in premature and $12 \%$ in mature infants and expressing results as percentage of lean (fat-free) body mass [31], diminishes the "water excess" in the premature group: mean APS per lean kilogxam becomes 846 $\mathrm{ml} / \mathrm{kg}$ in the premature infants and $782 \mathrm{ml} / \mathrm{kg}$ in the mature infants. These results are remarkably similar to the available carcass data for premature $(844 \mathrm{~g}$ water/ $\mathrm{kg}$ lat-free carcass) and mature neonates (808 $\mathrm{g}$ water/ $\mathrm{kg}$ fat-free carcass). Although these corrections diminish body water differences related to changes in fat with maturity, significant differences remain between mature and premature infants for both carcass $(P<$ $0.005)$ and the present in vivo data $(P<0.01)$. This observation suggests that $\triangle$ APS per kilogram with advancing fetal maturity is not entirely an indirect result of water displacement by fat but is, in fact, partially due to lean body mass becoming "less wet."

Total cell water correlates with many variables of fetal maturity, best fit being with length $(r=+0.852)$. Although ICW per kilogram varies with fetal maturity (Table III), recalculation on a "lean mass" basis diminishes these differences to a level of statistical nonsignificance (ICW per kilogram of lean mass in premature neonates becomes $39 \mathrm{l} \mathrm{ml} / \mathrm{kg}$ whereas ICW per kilogram of lean mass in mature infants becomes 368 $\mathrm{ml} / \mathrm{kg})$. Failure of the $\mathrm{ICW} / \mathrm{APS}$ ratio to correlate significantly with any parameter of maturity (Table II), as well as the nearly identical mean ICW/APS ratios of 0.47 in mature and 0.46 in premature $N G$ infants, provide further evidence that variations in ICW per kilogram with maturity in the present data are likely related to changes in total body fat.

Antipyrine spaces in the IGR infants are virtually identical to those in their NG weight peers, but compaxison with gestational (mature) peers reveals a significantly higher proportion of body weight occupied by water in the IGR group (Table III). In the absence of concurrent lat and water estimates, sparseness of fat or increased lean mass water are equally likely causes for these findings. If we presume total absence of fat in the mature IGR infant and $12 \%$ body fat in the mature NG infant, lean mass recalculations result in nearly identical APS per kilogram values in the two groups $(790 \mathrm{ml} / \mathrm{kg}$ in IGR and $782 \mathrm{ml} / \mathrm{kg}$ in $\mathrm{NG}$ infants). Ratios of ICW/APS are similar in IGR (0.46) and NG; mature groups (0.47), and mean ICW does not significantly differ in the two groups (Table III). Although these findings suggest that differences in body fat may explain the higher total intracellular (and even extracellular) water spaces in IGR neonates, it is pertinent to note that such a conclusion relies totally on the assumption that body lat is virtually absent in IGR newborns. Cionclusive tissue, carcass, anthropometric, or dilution data are not yet available on this point. Recent study of fatty acid metabolism in IGR neonates, in fact, suggests the contrary by inclirectly suggesting satisfactory availability of fat substrates [2].

An additional comment regarding these changes in IGR infants concens the early age at which infants in the present report were studied. Although restriction of study age to within $24 \mathrm{hr}$ of birth diminishes the effect of such extrinsic influences as nutrition, hydration, and renal maturation on body composition, it releases the powerful influence of events commonly compromising the perinate during labor and delivery [43]. Prominent among these events are the pathophysiologic sequences involved in cold stress and asphyxia. Cold 
stress depletes body stores of both carbohydrate and fat [30]. Assuming no concurrent alterations in permeability, metabolism, or binding of antipyrine and bromide, the depletion of fat for metabolic purposes would lead to a factitious increase in body water per kilogram, most apparent in the bromide compartment; an apparent (but not real) increase in the intracellular fraction of body water would be evident with later study age (postnatal age). Postnatal redistribution of body water was not apparent in premature infants in the present study. In mature infants, however, the precise opposite was observed (Fig. 2, Table IV); significant declines in APS/ICW occurred with late study age in both NG $(r=-0.76, P<0.01)$ and IGR infants $(r=-0.55, P<0.02)$. Similar results are evident using ratio standards; lower mean APS/kg: 841 versus 772 $P<0.02$, lower mean ICW $/ \mathrm{kg}: 494$ versus $335-P<$ 0.001 ; and lower mean ICW/APS: 0.56 versus $0.43-P$ $<0.001$ were observed in later-studied IGR infants and a similar trend was observed in the smaller group of NG infants. These postnatal changes, compatible with major extrusion of cell water and minor net loss of body water as study (postnatal) age advances in mature infants, suggest that fat metabolism did not influence these body water data.

In conclusion, speculation concerning those factors causing rapid decline in cell water after birth in mature infants is pertinent and of interest. Such factors may well be found in the pathophysiologic events of asphyxia. Impairment of cellular metabolism and composition have been shown to accompany degrees of hypoxia and acidosis far less severe than those observed during perinatal asphyxia [26, 35-38]. Inhibited cellular metabolism with increased cell acidity has a double osmolar effect-disturbance in function of the "cation pump" leads to accumulation of solute-containing water within cells, whereas diminished anionic activity of protein releases the ionic effectiveness of unbound cations $[26,36]$. Increased cell water in the recently born neonate may well result from impaired cellular metabolism consequent to asphyxial events normally accompanying labor and delivery. Exaggeration, persistence, or progression of compromised cellular metabolism might well be reflected in parallel changes of cell composition and volume whereas cell recovery would enable a (downward) readjustment of cell volume with advancing postnatal age.

Whether or not these events explain the postnatal body water adjustments in the present study is conjectural in the absence of concurrent appropriate acid- base studies. These considerations do, however, reveal that simple "correction" of the data for estimated body fat does not eliminate certain differences between NG and IGR mature infants. Comparison of early studied mature IGR infants reveals striking and significant elevations of body water, primarily intracellular in location, which persist even with "corrections" for fat.

\section{Summary}

Antipyrine dilution studies, performed within $24 \mathrm{hr}$ of birth in 44 normally grown, vaginally delivered neonates, yielded total body water estimates closely comparable to those accumulated from data obtained by desiccation analysis of 32 fetuses and newborn infants studied between 1863 and 1951. Concurrent bromide dilution studies, allowing estimation of cell water in these infants, suggested rapid postnatal extrusion of cell water in the 12 mature subjects. A sizable increase in body water per kilogram in the 32 premature infants persisted after correction for changes in body fat during growth, suggesting less hydration of lean mass with maturity. Also notable in the premature infants studied was postnatal failure to reduce cell water.

Similar studies in 23 mature, intrauterine growthretarded (IGR) neonates revealed body water volumes per kilogram which were similar to those observed in weight peers but larger than those seen in gestational peers. Similar to the mature, but in contrast to the premature infants studied, rapid downward adjustment of cell water took place in these IGR neonates. These prompt postnatal changes tended to obscure certain differences in cell and total body water, but consideration of the earlier-studied neonates revealed differences in body composition that persisted after correction for presumed total fat depletion in the IGR group. Most prominent of these changes in the IGR group was an increase in cell water in the early hours after birth.

Cumulative studies from this laboratory now conclusively reveal excessive plasma [8], extracellular [9], cell, and total body water dilution spaces per kilogram in IGR infants. Plasma volume and cell water expansion is particularly prominent in earlier-studied IGR neonates. Prompt, downward adjustments of cell and intravascular compartments [8] return these spaces to normal volumes within 4-6 hr, while more sluggish changes are observed in extracellular and total water compartments. These cross-sectional data must now be confirmed by similar but sequential studies accompanied by concurrent estimations of acid-base balance in order to determine whether the early excess of cell 
water is a consequence of impaired cellular metabolism and increased cellular acidity in these IGR infants.

\section{References and Notes}

1. Bischoff, E: Einige Gewichts und Trocken-Bestimmungen der Organe des menochlichen Korpers. Z. Ration. Med., 20: 75 (1863).

2. Blum, D., Dodion, J., Loeb, H., Wilkin, P., and Hubiniont, P. O.: Studies on hypoglycaemia in small-for-dates newborns. Arch. Dis. Childhood, 44: 304 (1969).

3. Brodie, B. B., and Axelron, J.: The fate of antipyrine in man. J. Pharmacol. Exp. Ther., 98: 97 (1950).

4. BRUBACHER, H.: Über den Gehalt an anorganischen stoffen, besonders an Kalk in den Knochen und Organen normaler und rachitischer Kinder. Z. Biol., 27: 517 (1890).

5. Camerer, W., Jr.: Die chemische Zusammensetzung des Neugeborenen. Z. Biol., 39: 173 (1900).

6. Camerer, W., Jr.: Die chemische Zusammensetzung des Ncugeborenen. Z. Biol., 40: 529 (1900).

7. Camerer, W., JR.: Die chemische Zusammensetzung des Neugeborenen Menschen. 7. Biol., 43: 1 (1902).

8. Cassady, G.: Plasma volume studics in low birth weight infants. Pediatrics, 38: 1020 (1966).

9. Cassady, G.: Bromide space studies in infants of low birth weight. Pediat. Res., 4: 14 (1970)

10. Cassady, G.: Body composition in intrautcrine growth retardation. Pediat. Clin. N. Amcr. 17: 79 (1970).

I1. Christian, J. R., Talso, P. J., Karazeris, M. P., Spafford, N. R., JACKSON, H., AND LARSON, M.: Total body water and exchangeable sodium in normal full-term newborn infants. Amer. J. Dis. Child., 92: 325 (1956).

12. Clapp, W. M., Butterfield, J., and O'Brien, D.: Body water compartments in the premature infant with special reference to the effects of the respiratory distress syndrome and of maternal diabetes and toxemia. Pediatrics, 29: 883 (1962).

13. Croxton, F. E.: Elementary Statistics with Applications in Medicine and the Biological Sciences. (Dover Publications, New York, 1959).

14. Drithine, C. M.: 'The small-for-date infant: etiology and prognosis. Pediat. Clin. N. Amer., 17: 9 (1970).

15. Fehring, H.: Beiträge zur Physiologie das placentaren stoffverkehrs. Arch. Gynäkol., 2: 523 (1877).

16. Fl.fxner, L. B., Whine, W. S., Proctor, N. K., Cowhe, D. B., Vosiburgh, G. J., and Hellman, L. M.: The estimation of extracellular and total body water in the newborn human infant with radioactive sodium and deuterium oxide. J. Pediat., 30: 413 (1947).

17. Frus-Hansen, B.: Changes in body water compartments during growth. Acta Pacdiat. Scand., 46: suppl. 110 (1957)

18. Fris-Hansen, B. J., Holmay, M., Stapleton, T., and Walrace, W. M.: Total body water in children. Pediatrics, 7: 321 (1951).

19. Garrow, J. S., Fretchir, K., and Hatidiay, D.: Body composition in severe infantile malnutrition. J. Clin. Invest., 44: $417(1965)$.

20. Garrow, J. S., Smitri, R., And Ward, E. E.: Electrolyte Metabolism in Severe Infantile Malnutrition. (Pergamon Press, London, 1968).

21. Givens, M. H., And Macy, I. G.: The chemical composition of the human fetus. J. Biol. Chem., 102: 7 (1933).
22. HANnA, F.: Total body water and its distribution. Amer. J. Dis. Child., 100: 723 (1960).

23. Huxr.ey, J. S.: Problems of Relative Growth. (I)ial Press, New York, 1932).

24. Iob, V., AND Swanson, W. W.: Mineral growth of the human fetus. Amer. J. Dis. Child., 47: 302 (1934).

25. Langstein, L., and Edelstein, F.: Die chemische Zusammensetzung frühgeborener Säuglinge und ihr Wachstumsansatz. Z. Kinderheilk., 15: 49 (1916).

26. LEAF, A.: Maintenance of concentration gradients and regulation of cell volume. Ann. N. Y. Acad. Sci., 72: 396 (1959).

27. LjuhGiren, H.: Measurement of total body water with deuterium oxide and antipyrine. Acta Physiol. Scand., 33: 69 (1955).

28. Lugo, G., and Cassady, G.: Intrauterine growth retardation: clinical findings in 233 consecutive cases. Amcr. J. Obstet. Gynecol., 109: 615 (1971).

29. Maclaurin, J. C.: Changes in body water distribution during the first two weeks of Iife. Arch. Dis. Childhood, 11:286 (1966).

30. Masoro, E. J.: Effect of cold on metabolic use of lipids. Physiol. Rev., 46: 67 (1966).

31. McCince, R. A., Anid Wudpowson, E. M.: A method of breaking down the body weights of living persons into terms of extracellular fluid, cell mass and fat, and some applications of it to physiology and medicine. Proc. Roy. Soc. Ser. B Biol. Sci., 138: $115(1951)$.

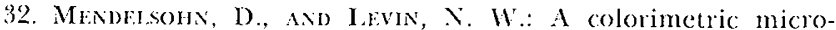
method for the estimation of antipyrine in plasma or serum. S. Afr. J. Med. Sci., 25: 13 (1960).

33. Michir., C.: Sur la composition chimique de l'embryon et du foctus humains aux differentes périodes de la grossesse. C. R. Seances Soc. Biol. Filiales, 51: 422 (1899).

34. Michri, C.: Sur la composition organique et minćrale du foetus et du nouveau-nć. Obstétrique, 5: 252 (1900).

35. Nerdham, J.: Chemical Embryology, Vol. 2, sect. 6, 12, and 13 (Cambridge University Press, London, 1931).

36. Platers, J. P.: Body Watcr: The Exchange of Fluids in Man, Chapt. 5, p. 120 (Charles (: Thomas, Springfield, III., 1935).

37. Rominson, J. R.: Metabolism of intracellular water. Physiol. Rev., 40: 112 (1960).

38. Rooth, G.: Acid-base, electrolyte and water changes during tissuc hypoxia in rats. (Clin. Sci., 30:417 (1966).

39. Schmmz, E.: Untersuchungen über den Kalkgehalt der wachsenden Frucht. Archiv. Gynakol., 121: I (1923).

40. Shom., A. T.: Mineral composition of the body. In: Mineral Metabolism, ed. 1, Chapt. 2, p. 13 (Reinhold Publishing Corporation, New York, 1939).

41. Smuir, N. W.: Total body water and bromide space determinations in premature infants. Amer. J. Dis. Child., 96: 494 (1958).

42. SöLDNF: Die chemische \%usammensetzung des Neugeborenen. Z. Biol., 44: 61 (1903).

43. Steviss, L. H.: Some principles in investigation and interpretation of metabolic bchaviour in the new-born. Australas. Ann. Med., 14: 146 (1965).

44. WeIL, W. B., JR.: Chemical composition of the fetus. In: $H$. L. Barnett: Pediatrics, ed. 14, p. 21 (Appleton-CenturyCrofts, New York, 1968). 
45. Widdowson, E. M., AND Spray, C. M.: Chemical development in utero. Arch. Dis. Childhood, 26: 205 (1951).

46. All procedures have been performed in accordance with the provisions set forth in the Declaration of Helsinki.

47. To the pediatric house staff and to Olivia Gibbons, the authors acknowledge their grateful appreciation.

48. Supported by Public Health Scrvice Research Grant no. R01
HD 02697 from the National Institute of Child Health and Human Development, National Institutes of Health.

49. Requests for reprints should be addressed to: George CASSADY, M.D., Director of Newborn Division and Newborn Nurseries, University of Alabama Medical Center, 1919 Seventh Avenue, South, Birmingham, Ala. 35233 (USA). 50. Accepted for publication January 21, 1971 . 